\title{
An operon encoding aspartokinase and purine phosphoribosyltransferase in Thermus flavus
}

\author{
Makoto Nishiyama, ${ }^{1}$ Mutsuko Kukimoto, ${ }^{2}$ Teruhiko Beppu ${ }^{1} \dagger$ and \\ Sueharu Horinouchi ${ }^{2}$
}

Author for correspondence: Makoto Nishiyama. Tel: +8133812 2111 ext. 3072 . Fax: +8135802 3326 .

Biotechnology Research Center ${ }^{1}$ and Department of Biotechnology2, The University of Tokyo, 1-1-1 Yayoi, Bunkyo-ku, Tokyo 113, Japan

\begin{abstract}
The nucleotide sequence of a $1.1 \mathrm{~kb}$ Xhol-HindIII fragment downstream of the malate dehydrogenase $(\mathrm{md} / \mathrm{h})$ gene of Thermus flavus revealed the presence of an ORF and an incomplete ORF lacking its $\mathrm{NH}_{2}$-terminal portion, in the opposite orientation to that of the molh gene. These two genes overlapped with each other, sharing two base pairs, suggesting that these genes are co-transcribed in a single mRNA. One ORF (termed gpt) encoded a protein of 154 amino acids showing significant amino acid sequence similarity to purine phosphoribosyltransferases, such as xanthine-guanine phosphoribosyltransferase of Escherichia colf and human hypoxanthine phosphoribosyltransferase. Cloning and sequencing of the upstream region of the gpt gene, together with sequence comparison of the gene product encoded by the region upstream of gpt, suggested that the upstream ORF encoded two in-frame overlapping aspartokinase genes, askA, encoding the $\alpha$ subunit of 405 amino acids, and askB, encoding the $\beta$-subunit of 161 amino acids, which was part of the $3^{\prime}$ portion of askA. Consistent with the sequence data, the askAB and the gpt genes conferred the heat-stable enzyme activities of aspartokinase and phosphoribosyltransferase, respectively, on E. coli. Preliminary characterization of these enzymes produced in E. colf is described.
\end{abstract}

Keywords: Thermus flavus, aspartokinase, end-product inhibition, purine phosphoribosyltransferase, thermostable enzyme

\section{INTRODUCTION}

We previously reported that the mdb gene encoding malate dehydrogenase in Thermus flavus AT-62 is transcribed as an operon containing the scs $A B$ genes encoding the $\alpha$ - and $\beta$-subunits of succinyl-CoA synthetase, in addition to the $m d b$ gene (Iijima et al., 1986; Nishiyama et al., 1986, 1991). In Escherichia coli, however, the mdh gene is transcribed in a monocistronic manner (Darlison et al., 1984) and is located at a genetic map position different from that of the major gene cluster for the enzymes involved in the tricarboxylic acid cycle (Darlison \& Guest, 1984; Spencer et al., 1984; Wood et al., 1984; Buck et al., 1985; Heard et al., 1975; Southerland \& McAlister-

† Present address: Department of Applied Biological Science, College of Agriculture and Veterinary Medicine, Nihon University, Kame-ino, Fujisawa, Kanagawa 252, Japan.

The GSDB/DDBJ/EMBLNCBI accession number for the nucleotide sequence reported in this paper is D37928.

Abbreviations: HPRT, hypoxanthine phosphoribosyltransferase; PRT, phosphoribosyltransferase; RBS, ribosome-binding site; XGPRT, xanthineguanine phosphoribosyltransferase.
Henn, 1985), which includes the sucCD genes encoding two subunits of succinyl-CoA synthetase. To clarify further the gene arrangement of the $m d b$ locus of $T$. flavus, we determined the nucleotide sequence of the region downstream of $m d h$. This analysis revealed the presence of genes encoding aspartokinase (ask $A B$ ) and purine phosphoribosyltransferase $(g p t)$, which are responsible for the biosynthesis of branched-chain amino acids and salvage synthesis of purine nucleotides, respectively. This paper describes the cloning and sequence analysis of the aspartokinase and the phosphoribosyltransferase (PRT) genes downstream of the mdh gene of T. flavus, along with preliminary characterization of the gene products.

\section{METHODS}

Enzymes and chemicals. Restriction endonucleases, T4 DNA ligase, and DNA polymerase I (Klenow fragment) were purchased from Takara Shuzo. $\left[\alpha{ }^{32} \mathrm{P}\right] \mathrm{dCTP}$ was from Amersham Japan. A kit for nucleotide sequencing by the M13dideoxy nucleotide method (Sanger et al., 1977) was obtained from USB. Oligonucleotides used were synthesized with a Cyclone Plus DNA synthesizer (Millipore). 
Bacterial strains and plasmids. E. coli $\mathrm{JM} 105[\Delta($ lac - pro $)$ thi $\operatorname{str} A$ end $A$ sbcB15 bsdR4 $\mathrm{F}^{\prime}$ traD36 pro $A B$ lacI ${ }^{q}$ lacZ $\left.Z \mathrm{M} 15\right]$ was used as a host for the expression of the gpt and ask genes and also for M13 phage propagation for determination of the nucleotide sequence.

Plasmid pTA101 (Iijima et al., 1986), which contains a $3.2 \mathrm{~kb}$ HindIII fragment carrying the $m d b$ gene of $T$. flawus AT- 62 was used as a DNA source for sequencing and chromosome walking. Plasmid pPRT101 for the expression of the gpt gene was constructed as follows. pUC19 digested with BamHI was treated with Klenow fragment and then digested with SacI. The resulting DNA fragment was ligated with the 1617 bp StuI-SacI fragment which covers the whole $g p t$ coding region to yield pPRT101. This plasmid allowed the expression of gpt under the control of the lac promoter of E. coli, where an AGAGG sequence in the multiple cloning cartridge, located $7 \mathrm{bp}$ upstream of the putative translation initiation codon ATG for the $g p t$ gene, could serve as the ribosome-binding site (RBS) for translation.

For expression of the ask $A B$ genes in $E$. coli, plasmid pAKT101 was constructed as follows. PCRs were done using pDMD101 constructed in this study as a template and two synthetic oligonucleotides as primers, 5'-CGAATTCCTAAAAGGAGGGAAGCATGGCCCT-3' and 5'-CAGCATCTGGTCGTAGCCGATGAC-3'. The former was designed to contain an EcoRI site just upstream of the putative RBS. This primer was also designed to maximize translational efficiency by replacing GTG of the ask $A$ gene with ATG as the initiation codon. The latter was derived from the AskA-encoding sequence (nt 787-810, see Fig. 1). The PCR conditions were $94^{\circ} \mathrm{C}$ for $1 \mathrm{~min}$, $50^{\circ} \mathrm{C}$ for $1 \mathrm{~min}$, and $72^{\circ} \mathrm{C}$ for $1 \mathrm{~min}$, with a total of 20 cycles. After digestion of the amplified DNA with EcoRI and HindIII, the resulting restriction fragment of about $600 \mathrm{bp}$ was ligated with the 860 bp HindIII-PstI fragment from pDMD101 and pUC18 digested with EcoRI plus PstI to yield pAKT101.

Another expression plasmid, pAKT102, was constructed as follows. Two synthetic oligonucleotides, 5'-GGCTCTAGATTAGGCCTTGTCCAGCTCAAAAGC-3', which was designed to introduce an $X b a I$ site just downstream of the stop codon TAA for the aspartokinase genes, and 5'-CACCTGATCCCCGAGGCGAGGAAG-3' (nt 757-780) were used as the primers for PCR with pDMD101 as the template, and the amplified DNA fragment was digested with both HindIII and $X b a I$. Additional PCRs using the oligonucleotides 5 '-CCTCTAGAAAGGAGGTGGACGATGGAGATGGACAAGGCG GTGACG-3' and 5'-GGGCATGC'TCTATCAGGCCT'TGTCCAGCTC-3', were carried out to introduce $X b a \mathrm{I}$ and $S p b \mathrm{I}$ restriction sites to the $5^{\prime}$ and $3^{\prime}$ termini of the ask $B$ gene, respectively, and the resulting amplified DNA was digested with both $X b a \mathrm{I}$ and $S p b \mathrm{I}$. The two restriction fragments thus prepared by PCR were ligated with the $\sim 600$ bp EcoRIHindIII fragment from pAKT101 containing the $\mathrm{NH}_{2}$-terminal portion of the $\alpha$-subunit of aspartokinase, and with pUC18 digested with both EcoRI and $S p b I$, and were introduced into E. coli JM105. The resulting plasmid, named pAKT102, contained the ask $A B$ genes and an additional copy of the askB gene. The nucleotide sequence of the junction region between the ask $A B$ and the additional askB genes was $5^{\prime}$ gccTAAtctagaaaggaggtggacgATGgagatg-3' (capitalized TAA and ATG represent the termination codon of ask $A B$ and the initiation codon of askB).

DNA manipulation. All the enzymes used for DNA manipulation were purchased from Takara Shuzo. Total chromosomal DNA of $T$. flavus was prepared by the method of Saito \& Miura (1963). For cloning the whole coding region of the ask $A$ gene, the 330 bp HindIII-XboI fragment containing a central portion of the aspartokinase gene was prepared by agarose gel electrophoresis and used as a probe for Southern hybridization (Southern, 1975). Colony hybridization was carried out by the method of Grunstein \& Hogness (1975). The nucleotide sequence was determined by the dideoxy chain-termination method using M13 phages (Sanger et al., 1977; Messing, 1983). All restriction sites used for cloning on M13 RFI DNA were verified by determination as part of an overlapping sequence.

Computer analysis of amino acid sequences. Amino acid sequence similarity was analysed using the protein databases of National Biomedical Research Foundation and EMBL with the GENETYX-CD software (Software Development).

Expression of gpt. E. coli cells harbouring pPRT101 were precultured in $10 \mathrm{ml} 2 \times$ YT medium (Yanisch-Perron et al., 1985) supplemented with $50 \mu \mathrm{g}$ ampicillin $\mathrm{ml}^{-1}$ at $37^{\circ} \mathrm{C}$. Preculture $(1 \mathrm{ml})$ was transferred to $100 \mathrm{ml}$ of the same medium and cultured for $2 \mathrm{~h}$. IPTG was then added to give a concentration of $1 \mathrm{mM}$ and cultivation was continued for an additional $12 \mathrm{~h}$. The cells were harvested by centrifugation, suspended in $4 \mathrm{ml}$ $100 \mathrm{mM}$ potassium phosphate buffer $(\mathrm{pH} 7 \cdot 0$ ), and disrupted by sonication (Branson Sonifier, cell disrupter model 250). After centrifugation of the sonicate at $10000 \mathrm{~g}$ for $30 \mathrm{~min}$, the supernatant was heated at $70^{\circ} \mathrm{C}$ for $30 \mathrm{~min}$, which completely inactivated the purine PRT activity present in the $E$. coli host cells. The crude enzyme solution was obtained after centrifugation of the heated extract at $10000 \mathrm{~g}$ for $30 \mathrm{~min}$.

Expression of askAB. E. coli cells carrying pAKT101 or pAKT102 were precultured at $37^{\circ} \mathrm{C}$ in $10 \mathrm{ml} 2 \times$ YT medium containing $50 \mu \mathrm{g}$ ampicillin $\mathrm{ml}^{-1}$. Pre-culture $(100 \mu \mathrm{l})$ was transferred to $10 \mathrm{ml}$ of the same medium supplemented with $1 \mathrm{mM}$ IPTG and cultivation was continued for another $12 \mathrm{~h}$. The cells were harvested by centrifugation, suspended in $500 \mu \mathrm{l}$ $100 \mathrm{mM}$ Tris/ $\mathrm{HCl}$ buffer ( $\mathrm{pH} \mathrm{7.5)}$, and disrupted by sonication. The sonicates were then centrifuged at $16000 \mathrm{~g}$ for $10 \mathrm{~min}$ and heated at $70^{\circ} \mathrm{C}$ for $30 \mathrm{~min}$. After centrifugation of the heattreated solution at $16000 \mathrm{~g}$, the supernatant was used as the crude enzyme solution.

Enzyme assay. PRT activities were assayed at $37^{\circ} \mathrm{C}$. The reaction mixture contained $10 \mathrm{mM} \mathrm{MgCl}_{2}, 20 \mathrm{mM} \mathrm{NaF}, 5 \mathrm{mM}$ 5-phosphoribosyl 1-pyrophosphate, $1.25 \mathrm{mM}$ of each purine base (xanthine, hypoxanthine or adenine), and an appropriate amount of heat-treated cell extract in $100 \mathrm{mM}$ Tris $/ \mathrm{HCl}$ $(\mathrm{pH} 7 \cdot 0)$. For determination of activity with guanine, the concentration of guanine in the reaction mixture was set at $0.5 \mathrm{mM}$ due to the lower solubility of this compound in water. After an appropriate period of incubation, the reaction was stopped by 20 -fold dilution with distilled water. The conversion of the purine base to the corresponding nucleotide monophosphate was analysed by HPLC (Shimadzu) equipped with a Senshu ODS VP-1151 column $(4 \cdot 6 \times 150 \mathrm{~mm})$ using $100 \mathrm{mM}$ $\mathrm{KH}_{2} \mathrm{PO}_{4}(\mathrm{pH} \mathrm{5.0})$ as eluent at a flow rate of $1.0 \mathrm{ml} \mathrm{min}{ }^{-1}$ at $50^{\circ} \mathrm{C}$. The amounts of the substrates and products were estimated by measuring the absorbance at $260 \mathrm{~nm}$. One unit (U) of enzyme activity was defined as the amount of enzyme which catalysed the formation of $1 \mu \mathrm{mol}$ nucleotide $\mathrm{min}^{-1}$ from the corresponding purine. Proteins were determined by the method of Lowry or of Bradford (1976).

Aspartokinase activity was determined by the method of Cohen (1985) with some modifications. The reaction mixture of $780 \mu \mathrm{l}$, which contained an appropriate amount of enzyme preparation, $0.9 \mathrm{M} \mathrm{KCl}, 6.4 \mathrm{mM} \mathrm{ATP}, 54 \mathrm{mM} \mathrm{MgSO}_{4} .7 \mathrm{H}_{2} \mathrm{O}$ and $13 \mathrm{mM}$ potassium L-aspartate in $0.45 \mathrm{M}$ Tris $/ \mathrm{HCl}$ buffer $(\mathrm{pH} 7.4$ ), was incubated at $65^{\circ} \mathrm{C}$ for $5 \mathrm{~min}$. The reaction was then stopped by rapid cooling in ice-water. Phosphoenolpyruvate $(100 \mu \mathrm{l})$ and NADH $(100 \mu \mathrm{l})$ were added to give a concentration of $0 \cdot 1 \mathrm{mM}$ 
of each and the reaction mixture was preincubated at $37^{\circ} \mathrm{C}$ for $3 \mathrm{~min}$. Lactate dehydrogenase ( $5 \mu \mathrm{l}$, rabbit muscle type II, $50 \mathrm{U}$, Sigma) and pyruvate kinase ( $5 \mu$, rabbit skeletal muscle type II, $10 \mathrm{U}$, Sigma) were then added to the reaction mixture, and the decrease in $A_{340}$ due to the decrease in NADH was monitored using a spectrophotometer (Milton Roy Spectronic 3000 array or Shimadzu $160 \mathrm{~A}$ ). One unit was defined as the amount of enzyme which catalysed the oxidation of $1 \mu \mathrm{mol} \mathrm{NADH} \mathrm{min}^{-1}$ under the conditions described above. To determine the thermostability of aspartokinase, the remaining activity after heat treatment of the enzyme preparation at various temperatures for $30 \mathrm{~min}$ was measured. Inhibition of the aspartokinase activity by lysine and threonine was examined by adding the amino acids to the reaction mixture at a concentration of $1 \mathrm{mM}$.

\section{RESULTS}

\section{Nucleotide sequence of the region downstream of molh from $T$. flavus}

We had already determined the nucleotide sequence of the $2.1 \mathrm{~kb}$ HindIII-XhoI segment of the $3.2 \mathrm{~kb}$ HindIII fragment cloned in pTA101, containing the $m d b$ gene from T. flavus (Nishiyama et al., 1986). In the present study, the $1.1 \mathrm{~kb}$ XhoI-HindIII fragment located downstream of $m d b$ was sequenced and two ORFs in the opposite orientation to that of the $m d b$ operon were found (Fig. 1). An ORF of 154 amino acids (17103 Da) started from the initiation codon ATG (nt 1425-1427), and was preceded by a putative RBS, GGACAAG, with a 5 bp space, and terminated at TAA (nt 1887-1889). By computer-aided analysis, this ORF was found to encode a protein with significant sequence similarity to that of the xanthine-guanine PRT (XGPRT) of E. coli (Pratt \& Subramani, 1983), and the human hypoxanthine PRT (HPR T) (Jolly et al., 1983) (Fig. 2a). We concluded that this ORF encoded a purine PRT of T. flavus, because, as will be described below, this ORF specified heat-stable purine PRT activities in E. coli. We therefore designated the gene encoding this ORF as $g p t$. Another ORF (nt 778-1422) was found within the sequenced region but was obviously incomplete because of the absence of a start codon and RBS. However, the truncated ORF was found to code for a COOH-terminal portion of an enzyme whose amino acid sequence showed significant similarity to those of aspartokinases from E. coli (Katinka et al., 1980; Zakin et al., 1983; Cassan et al., 1986), Bacillus subtilis (Chen et al., 1987), and Corynebacterium glutamicum (Kalinowski et al., 1991). Because of the high similarity of the Thermus aspartokinase to those of $B$. subtilis and $C$. glutamicum, we expected that it might also be encoded by in-phase overlapping genes, as is the case for the aspartokinases from these Gram-positive bacteria. We therefore tentatively named the gene(s) ask $A$ and ask $B$ for the large $(\alpha)$ and the small $(\beta)$ subunits, respectively.

\section{Structure of askAB from $T$. flavus}

Since the $3.2 \mathrm{~kb}$ HindIII fragment which had already been cloned contained the whole askB coding region, but appeared to lack the complete ask $A$ gene, chromosome walking was used to obtain a DNA fragment containing the $5^{\prime}$ terminal portion of the ask $A$ gene. When the $T$. flavus chromosomal DNA digested with several restriction endonucleases was subjected to Southern hybridization with a HindIII-XboI fragment (about $330 \mathrm{bp}$ ) containing a central part of the ask $A$ gene as the probe, a single PstI fragment of approximately $1.7 \mathrm{~kb}$ gave positive hybridization (data not shown). The $1.7 \mathrm{~kb}$ PstI fragment was recovered from agarose gels, inserted into the Pst $\mathrm{I}$ site of pUC19, and introduced into E. coli JM105. Three colonies among several hundred transformants gave positive hybridization with the probe, and the plasmids recovered from the three positive transformants possessed an identical $1.7 \mathrm{~kb}$ PstI fragment containing the ask $A B$ genes from $T$. flavus. One of the these plasmids was designated $\mathrm{pDMD101}$. A long ORF (ask $A$ ) of 405 amino acids $(43318 \mathrm{Da})$ was identified by sequencing the cloned PstI fragment; there is a potential RBS, AAGGAGG, $5 \mathrm{bp}$ in front of the putative initiation codon GTG of the ask $A$ gene (Fig. 1).

When the deduced amino acid sequence of Thermus aspartokinase was compared with several other aspartokinases that were already sequenced, stronger similarity was found with aspartokinases from Gram-positive bacteria, such as $C$. glutamicum aspartokinase (46\%) and $B$. subtilis aspartokinase II (45\%), than with E. coli aspartokinase III $(30 \%)$ (Fig. 2b). The aspartokinases of $B$. subtilis and $C$. glutamicum are tetrameric, and are composed of equal amounts of the $\alpha$ - and the $\beta$-subunits $\left(\alpha_{2} \beta_{2}\right)$, encoded by in-phase overlapping genes. In both cases, the initiation codon for the $\beta$-subunit is located within the $\alpha$ subunit-encoding region, and is preceded by a typical RBS. A similar situation for the $\beta$-subunit of $T$. flavus was observed: a methionine codon at the position corresponding to the putative initiation codon for the $\beta$ subunit was present and preceded by a potential RBS, AAGGAGG, with a 5 bp space. This suggested that the aspartokinase of $T$. flavus was composed of two subunits encoded by in-phase overlapping genes, as is the case for those of B. subtilis and C. glutamicum. These findings strongly suggested that the ask $B$ gene corresponded to the $3^{\prime}$ portion of ask $A$ and that it coded for a protein of 161 amino acids (16894 Da).

A possible promoter sequence (nt 138-166, $5^{\prime}$-TTGGGC$17 \mathrm{bp}$-TAACAT- $3^{\prime}$ ) is found $41 \mathrm{bp}$ upstream of the initiation codon for ask $A$. The termination codon for the ask $A B$ genes, TGA, overlapped with the putative initiation codon, ATG, of the gpt gene, sharing two bases, $T$ and $G$. In addition, inverted repeat sequences capable of forming stable stem-loop structures, probably serving as $\rho$-independent transcriptional terminators, were found downstream of the gpt gene. These observations suggest that the ask $A B$ and $g p t$ genes are co-transcribed in a single mRNA as an operon.

An additional ORF was found in the region upstream of the ask $A B$ genes in the opposite orientation to that of the ask $A B$ genes (Fig. 1). The amino acid sequence of this ORF, however, showed no sequence similarity to the protein sequences deposited in the EMBL or the NBRF databases. 


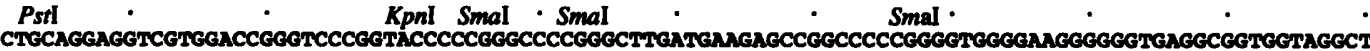

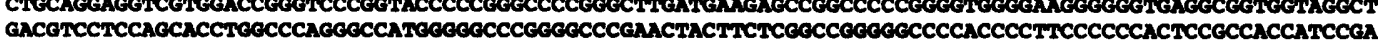
GInLeuLeuAspHisvalProAepArgTy

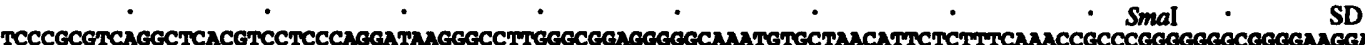

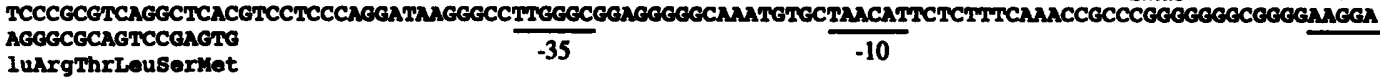

$\frac{-35}{-10}$

askA

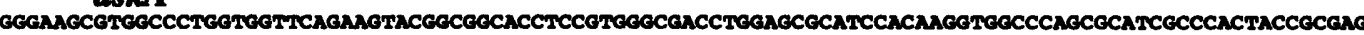

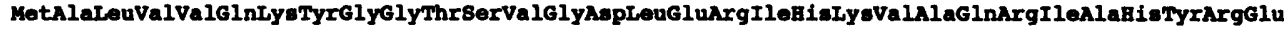

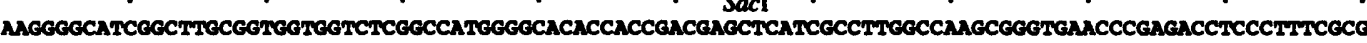

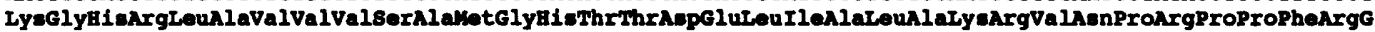

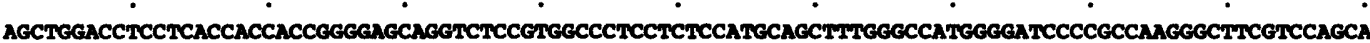
luLeuAspLeuLeuThrThrThrGl yGluGlnvalservalAlaLeuLeuserMetGlnLeuTrpAlaMetGlyI leProAlaLyaGlyPhevalGlnH 1

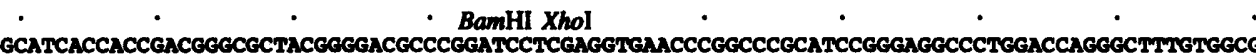

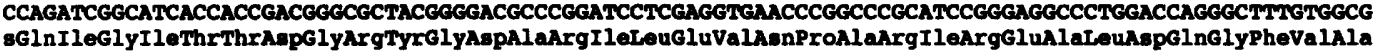

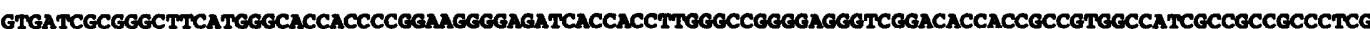
ValI leAlaGlyPheNetGlyThrThrProGluGlyGluI leThrThrLeuGlyArgGlyGlyserAgpThrThrAlavalAlarleAlaAlaAlaLeuG

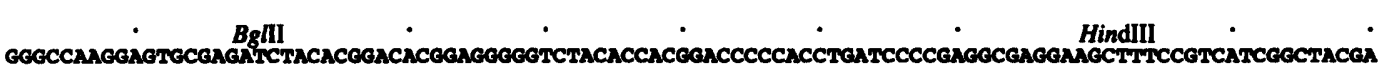

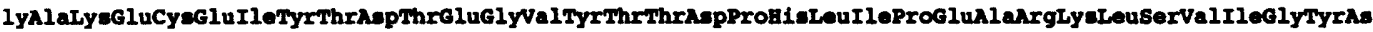

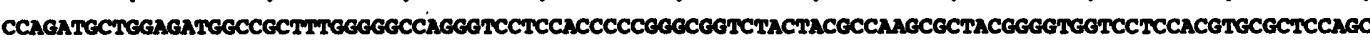

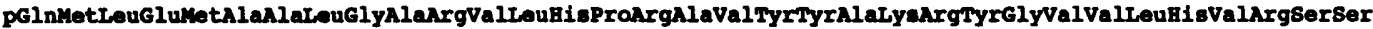

SD askB

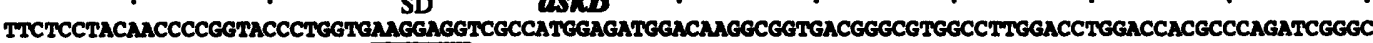

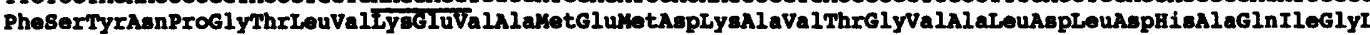

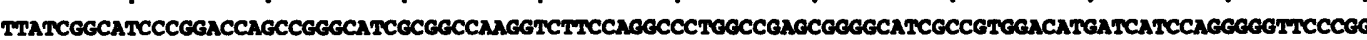

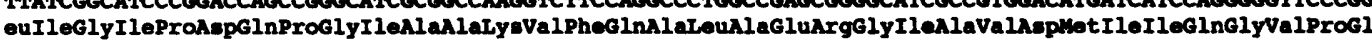

- Xhol •

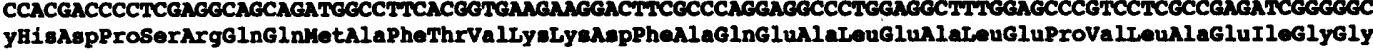

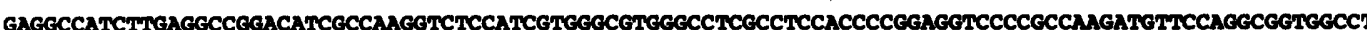
GluAlarleLeuArgProAepIleAlaLyevalserI levalGlyvalGlyLeuAlaserThrProgluvalproAlaLymMetPheglnAlavalAlas

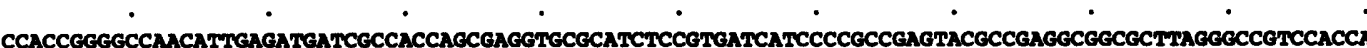
erThrGlyAlaAsnIlegluMetIleAlaThrSerGluvalArgIleservalIleIleProAlagluTyrAlagluAlaAlaLeuArgAlavalBiegl

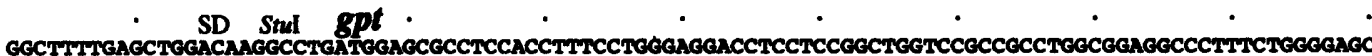

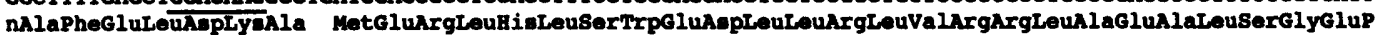

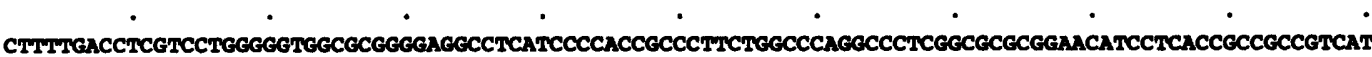
ropheAspLeuvalleuGlyvalAlaArgGlyGlyLeurleProThrAlaLeuieuAlaGlnAlateuGlyAlaArgAsnIleLeuThxAlaAlavalMe

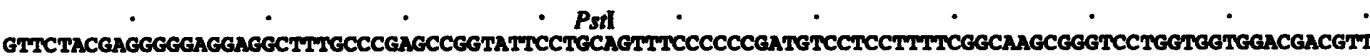

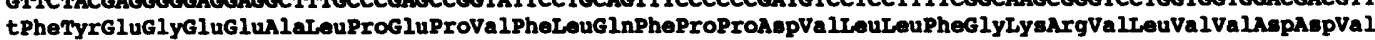

TGGGACTCGGGGCGCACGGCCTPTGCCGTGNAGCCCCGGGTECOCCGAGCGGGCGGGGTGCCTGTEGTGGCCACCCTCCACTTCAAGCCGGGGCGGACC

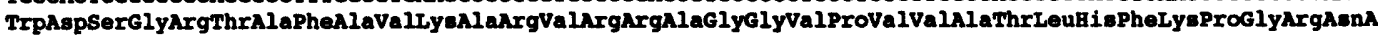

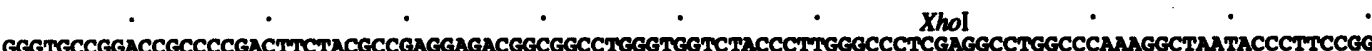
rgValProAspArgProAspPeTyrAlaGluGluThrAlaAlaTrpVaIValTyrProTrpAlaLeuGluAlaTrpProLyeGly

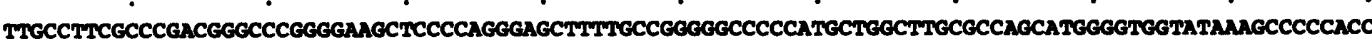

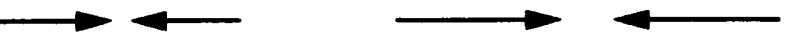

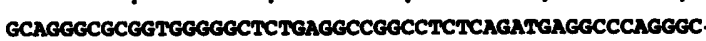

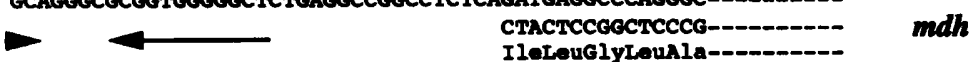

Fig. 1. Nucleotide sequence of the genes encoding aspartokinase and purine PRT from $T$. flavus. Converging arrows represent inverted repeat sequences. 
(a)

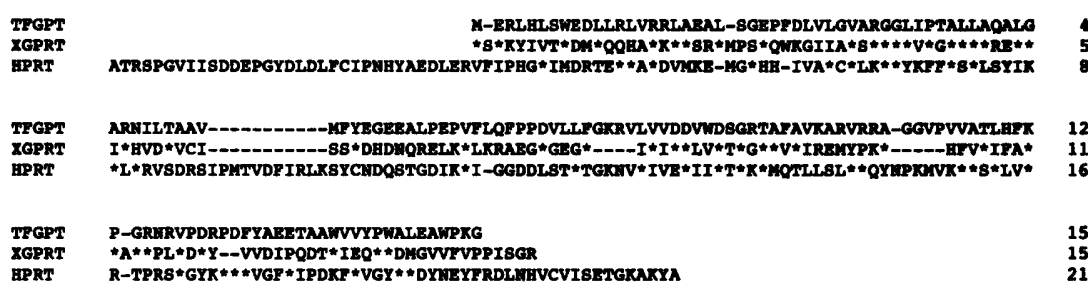

(b)

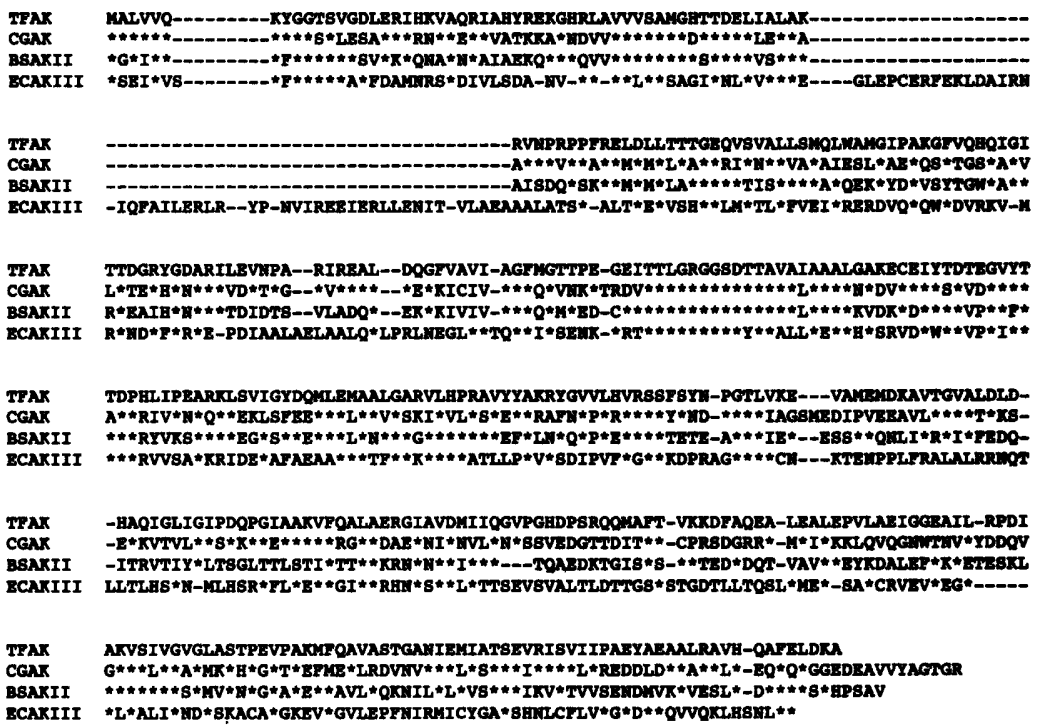

49
Fig. 2. Comparison of the amino acid sequences of (a) purine PRT and (b) aspartokinase. TFGPT, purine PRT from $T$. flavus; XGPRT, xanthine-guanine PRT from E. coli; human HPRT, hypoxanthine PRT; TFAK, aspartokinase from T. flavus; CGAK, aspartokinase from C. glutamicum; BSAKII, aspartokinase II from B. subtilis; ECAKIII, aspartokinase III from $E$. coli. Asterisks denote amino acids identical to those of $T$. flavus enzymes.

\section{Expression of gpt in E. coli}

To detect the enzyme activity encoded by $g p t$, we constructed plasmid pPRT101, which allowed the expression of $g p t$ under the control of the lac promoter on pUC19. A crude extract prepared from E. coli JM105 harbouring pPRT101 was analysed by SDS-PAGE. As shown in Fig. 3, a heat-stable protein with a molecular mass of $17 \mathrm{kDa}$, which was in good agreement with the molecular mass deduced from the nucleotide sequence of the $g p t$ gene, was detected in the crude extract prepared from the E. coli transformant, while no such heat-resistant protein was found when the crude extract from E. coli without the plasmid was similarly analysed.

Then the PRT activity in the heat-treated extract of E. coli harbouring PPRT101 was examined. Since heat-treatment of E. coli extracts at $70^{\circ} \mathrm{C}$ for $30 \mathrm{~min}$ completely inactivated the native PRT (data not shown), the heated crude extract was used for the analysis of Thermus purine PRT activity. The reaction was carried out using adenine, hypoxanthine, xanthine or guanine as the substrate (Fig. 4). Conversion of the purine to the corresponding purine nucleotide monophosphate was observed when hypoxanthine, xanthine or guanine were used as the substrates, but not when adenine was used. The specific activities of this PRT with guanine $\left[22.0 \mathrm{U}(\mathrm{mg} \text { protein })^{-1}\right]$, hypoxanthine $\left[19.7 \mathrm{U}(\mathrm{mg} \text { protein })^{-1}\right]$ and xanthine $[23.9 \mathrm{U}$ (mg protein $)^{-1}$ ] were very similar.

\section{Expression of askAB in E. coli}

For expression of the ask $A B$ genes in $E$. coli, we constructed two plasmids, pAKT101 and pAKT102, both of which allowed the expression of the ask $A B$ genes under the control of the lac promoter on pUC18. E. coli cells carrying pAKT101 or pAKT102 were harvested and fractionated into soluble and insoluble fractions by centrifugation, and the soluble fractions were subjected to heat-treatment at $70{ }^{\circ} \mathrm{C}$ for $30 \mathrm{~min}$. When each fraction was analysed by SDS-PAGE, a heat-stable protein of $43 \mathrm{kDa}$, which corresponds to the molecular mass of the $\alpha$-subunit of the aspartokinase from $T$. flavus, was found mainly in the soluble fractions of both transformants (Fig. 5). However, a $17 \mathrm{kDa}$ protein, which corresponded to the $\beta$-subunit, was not found in any fraction prepared from $E$. coli harbouring pAKT101, even when the fractions were heated to remove heat-labile proteins from the $E$. coli host. This result suggests that, in $E$. coli harbouring pAKT101, only the $\alpha$-subunit, and not the $\beta$ subunit, was translated from the intact ask $A B$ genes. However, E. coli harbouring pAKT102 containing an additional copy of the $\beta$-subunit gene just downstream of the original ask $A B$ operon produced a heat-stable protein of $17 \mathrm{kDa}$. When the aspartokinase activities were measured with these two heat-treated preparations, the specific activities conferred by pAKT101 and pAKT102 were $21.5 \mathrm{U}$ (mg protein $)^{-1}$ and $12.7 \mathrm{U}(\mathrm{mg} \text { protein })^{-1}$, respectively, which seemed to be proportional to the 


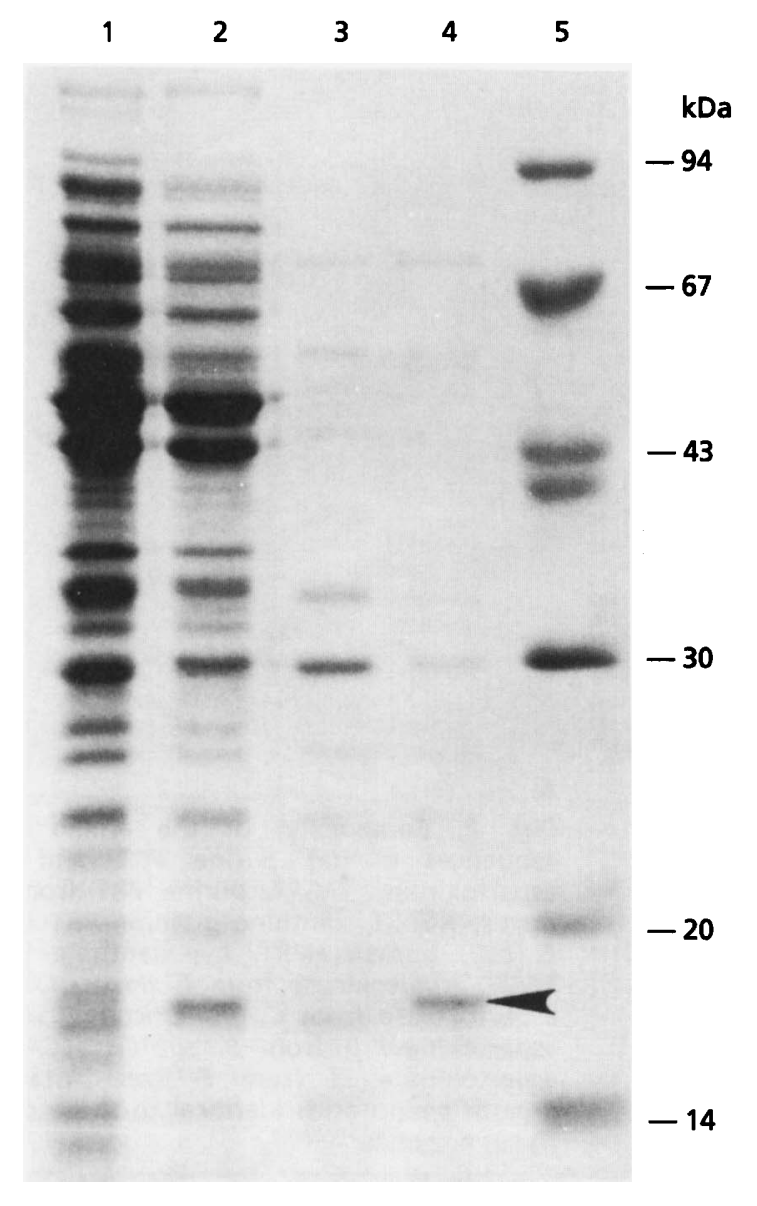

Fig. 3. Production of purine PRT from $T$. flavus in E. coli. Lane 1, supernatant of the extract of $E$. coli JM105 grown with IPTG; lane 2, supernatant of the extract of $E$. coli JM105 harbouring PPRT101 grown with IPTG; lanes 3 and 4, same as lanes 1 and 2, respectively, but supernatants were heated at $70^{\circ} \mathrm{C}$ to denature heat-labile proteins. The purine PRT directed by pPRT101 is indicated by an arrowhead. Molecular mass markers (lane 5) are: phosphorylase b $(94 \mathrm{kDa})$, BSA $(67 \mathrm{kDa})$, ovalbumin $(43 \mathrm{kDa})$, carbonic anhydrase $(30 \mathrm{kDa})$, soybean trypsin inhibitor $(20 \mathrm{kDa})$ and $\alpha$-lactalbumin (14 kDa).

amounts of the $\alpha$-subunit of aspartokinase produced (see Fig. 5). No difference in the thermostability or the temperature-activity-profile of aspartokinase activities was observed between these two preparations (Fig. 6). Both aspartokinase preparations had activity which was stable up to $80^{\circ} \mathrm{C}$, and each had a temperature-activity profile with an optimum temperature of $75^{\circ} \mathrm{C}$.

We next examined the effects of lysine and threonine on the enzyme activity, because the aspartokinases from $C$. glutamicum and $B$. subtilis are inhibited by the end-products (lysine plus threonine and lysine only, respectively) of the branched amino acid biosynthesis pathway, starting from aspartate through feedback inhibition (Tosaka et al., 1983; Moir \& Paulus, 1977). As shown in Table 1, the aspartokinase activities in both extracts were decreased by the addition of threonine, but were not significantly decreased by lysine. When lysine was added to the reaction
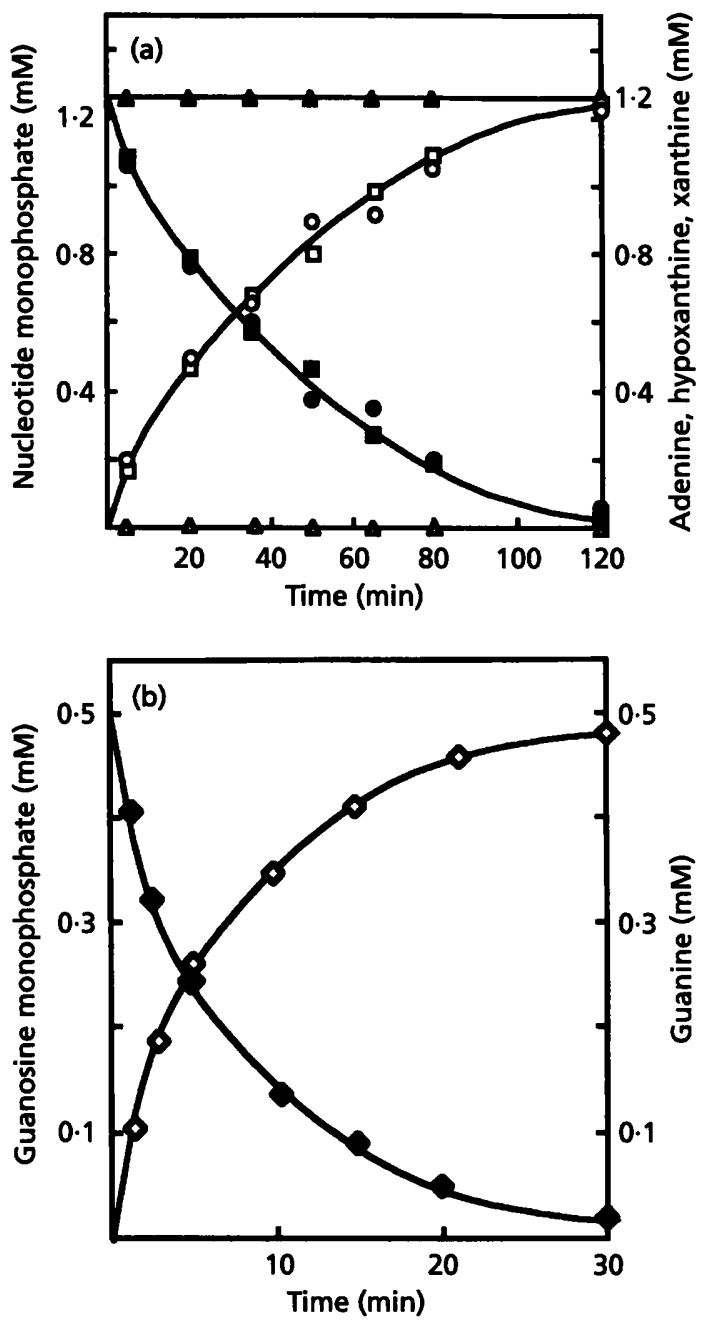

Fig. 4. Time-course for the formation of nucleotide monophosphates with (a) adenine, hypoxanthine or xanthine as substrate, and (b) guanine as substrate. $O$, Xanthosine monophosphate; $\square$, inosine monophosphate; $\Delta$, adenosine monophosphate; $\diamond$, guanosine monophosphate; $\bullet$, xanthine; $\square$, hypoxanthine; $\Delta$, adenine; $\bullet$, guanosine.

mixtures simultaneously with threonine, no further decrease in the enzyme activity was observed. Although the aspartokinase activity in both crude extracts was modulated only by threonine, the sensitivity to threonine of the two preparations was different. Addition of threonine to the extract from E. coli harbouring pAKT102 caused a marked decrease in the activity $(5-10 \%$ of the original activity remaining), whereas addition of threonine had a smaller effect on the activity in the aspartokinase preparation of E. coli harbouring pAKT101 (about 30\% remaining).

\section{DISCUSSION}

This study together with our previous study has revealed the architecture. of two operons (ask $A B-g p t$ and $s c s A B-m d b)$ of $T$. flavus. The aspartokinase genes of $C$. glutamicum and Mycobacterium smegmatis were shown to be 


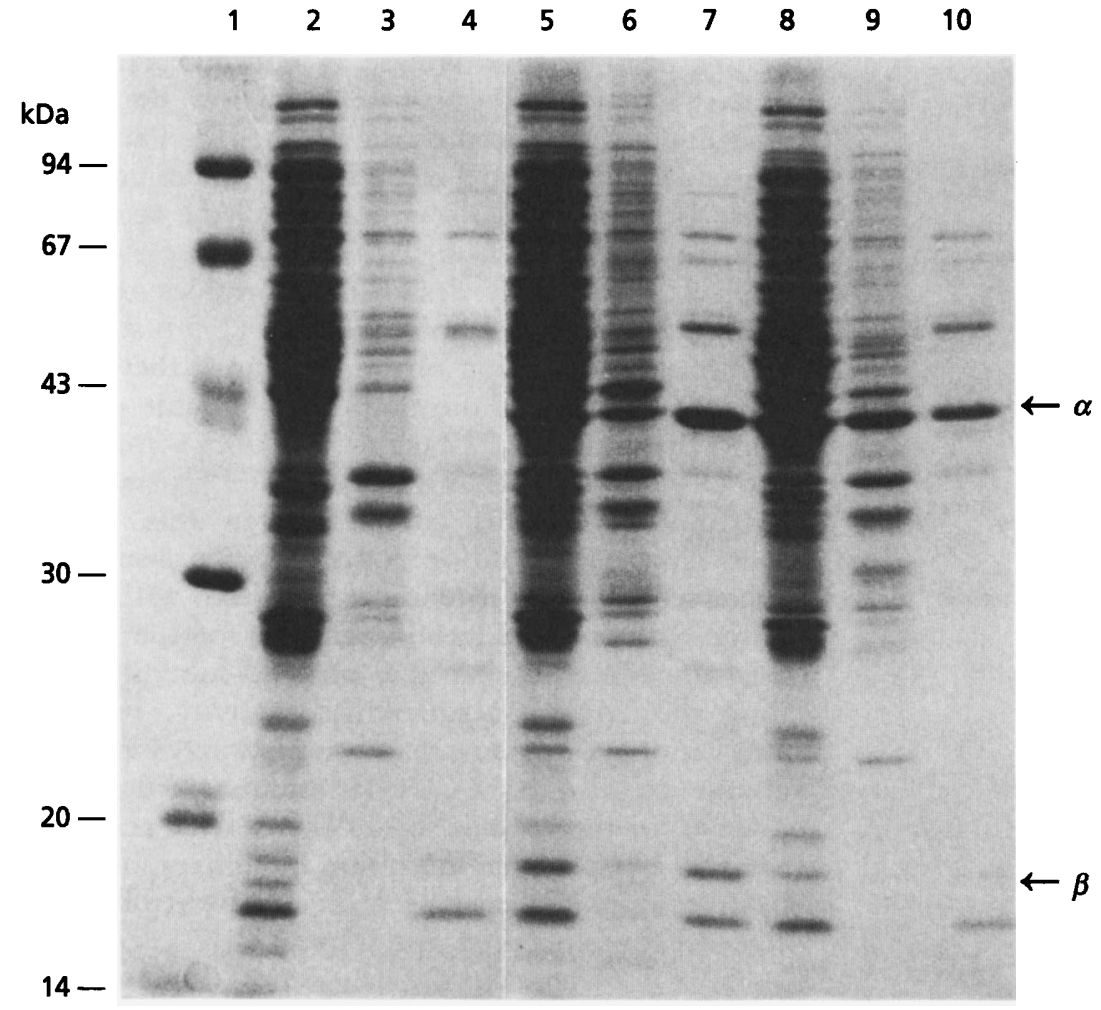

Fig. 5. Production of aspartokinase from $T$. flavus in $E$. coli. Lane 1 , molecular mass markers; lanes 2-4, E. coli JM105 cultured with IPTG as the control; lanes 5-7, E. coli JM105 harbouring PAKT102 cultured in the presence of IPTG; lanes 8-10, E. coli JM105 harbouring PAKT101 cultured in the presence of IPTG; lanes 2, 5 and 8 , supernatants of the sonicates of the $E$. coli cells; lanes 3, 6 and 9, precipitates of the sonicates of the $E$. coli cells; lanes 4,7 and 10 , supernatant of the sonicates after heattreatment at $70^{\circ} \mathrm{C}$ for $30 \mathrm{~min}$. The $\alpha$ - and $\beta$ subunits of aspartokinase are arrowed.

adjacent to the gene encoding aspartate semialdehyde dehydrogenase, which catalyses the conversion of aspartylphosphate, formed by the aspartokinase, to aspartate semialdehyde, and were therefore assumed to be co-transcribed as a single mRNA (Kalinowski et al., 1990; Cirillo et al., 1994). In E. coli possessing three aspartokinases, two of the three aspartokinase genes are included in gene clusters for biosynthesis of methionine and threonine (Theze \& Saint Girons, 1974; Duchange et al., 1983). However, the aspartokinase II of $B$. subtilis is translated from a monocistronic mRNA (Chen et al., 1989). In T. flavus, the aspartokinase genes probably form an operon with the gene encoding purine PRT, because the ask $A B$ genes are close to the purine PRT gene and share two bases. Thus the arrangement around the aspartokinase gene of $T$. flavus is totally different from those of other bacteria.

The promoter region of the aspartokinase II gene of $B$. subtilis contains a short region capable of encoding a lysine-rich peptide, which overlaps with the region of several dyad symmetries to function as an attenuator element controlling the expression of the aspartokinase gene(s) in response to the availability of lysine (Lu et al., 1992). No such short reading frame was present in the upstream region of ask $A$ of T. flavus. This observation may suggest the presence of some other regulatory mechanism for the expression of the aspartokinase genes. It is also of interest to reveal how the expression of this operon is regulated, because it comprises the genes responsible for two independent biosynthetic pathways: aspartokinase is responsible for amino acid biosynthesis and purine PRT is responsible for salvage synthesis of nucleotides. Transcriptional analysis of this operon is necessary to clarify the regulatory mechanism for its expression.

Aspartokinase catalyses the first step of the branched biosynthetic pathway for lysine, threonine, isoleucine and methionine, and is known to be regulated by the endmetabolites through feedback inhibition. For example, the activity of aspartokinase II of $B$. subtilis is regulated by lysine, while the aspartokinase activity of $C$. glutamicum was concertedly inhibited by lysine plus threonine. In the case of the aspartokinase of $T$. flavus, the activity was inhibited only by threonine. In spite of the relatively high sequence similarity, the amino acid residues of aspartokinase, which are responsible for modulation of the enzyme activity via end-product inhibition, are still unknown. Site-directed mutagenesis based on the sequence similarity along with determination of threedimensional structure will be required to clarify the mechanism for controlling the enzyme activity.

Two expression plasmids for the aspartokinase from $T$. flavus were constructed, one, pAKT101, with the original ask $A B$ genes downstream of the lac promoter and the other, pAKT102, having a structure similar to that of pAKT101 but with an additional copy of the askB gene downstream of the ask $A B$ genes. Both constructs directed the production of the $\alpha$-subunit, but only pAKT102 gave the detectable production of the $\beta$-subunit in E. coli. This suggests that a potential RBS for the $\beta$-subunit, located in the middle of the ask $A$ gene, did not function efficiently for the translation of the $\beta$-subunit in E. coli, and that the 

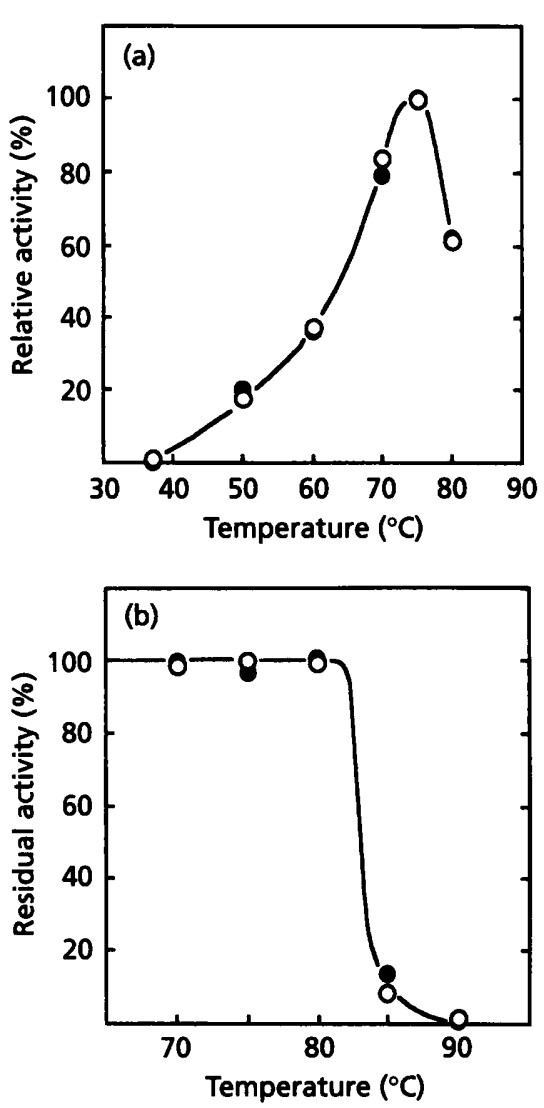

Fig. 6. Temperature-activity profile (a) and thermostability (b) of aspartokinase from $T$. flavus. Aspartokinase prepared from $E$. coli harbouring pAKT102; $O$, aspartokinase prepared from $E$. coli harbouring PAKT101. Thermostability was determined by measuring residual activity after heat-treatment at indicated temperatures for $30 \mathrm{~min}$. Control activities were $6.6 \times 10^{-2} \cup$ for aspartokinase prepared from $E$. coli harbouring pAKT102 and $2.6 \times 10^{-2} \mathrm{U}$ for aspartokinase prepared from $E$. coli harbouring PAKT101, respectively.

Table 1. Feedback inhibition of aspartokinase from $T$. flavus

\begin{tabular}{|ccccc|}
\hline \multicolumn{2}{|c}{ Amino acid (1 mM) } & & \multicolumn{3}{c|}{ Relative aspartokinase activity (\%) } \\
\cline { 1 - 2 } \cline { 5 - 5 } Lysine & Threonoine & & pAKT101 & pAKT102 \\
\hline- & - & & $100^{*}$ & \\
\hline & - & & $90 \pm 3$ & $100 \dagger$ \\
- & + & & $27 \pm 4$ & $90 \pm 5$ \\
+ & + & & $28 \pm 3$ & $6 \pm 1$ \\
\hline
\end{tabular}

* Control activity was $2.6 \times 10^{-2} \mathrm{U}$.

†Control activity was $6.6 \times 10^{-2} \mathrm{U}$.

$\beta$-subunit produced in E. coli carrying pAKT102 was mostly translated from the transcript derived from the additional ask $B$ gene connected downstream of the ask $A B$ genes. These two aspartokinase preparations had almost the same thermostability and temperature-activityprofile. Furthermore, both aspartokinase preparations showed sensitivity to threonine. This suggests that the $\beta$ subunit of the aspartokinase is not necessary for the primary function of the enzyme. Until now, the role of the $\beta$-subunit had not been clarified. Chen \& Paulus (1988) suggested no functional role for the $\beta$-subunit of aspartokinase II from $B$. subtilis either in enzyme activity or in feedback inhibition using an $E$. coli expression system which was artificially designed to produce only the $\alpha$ subunit. However, Kalinowski et al. (1990) suggested a functional contribution of the $\beta$-subunit; they observed that introduction of the mutated $\beta$-subunit gene from aminoethylcysteine-resistant $C$. glutamicum into a wildtype $C$. glutamicum strain caused partial resistance of the aspartokinase to this compound. In this study the aspartokinase preparation containing the $\beta$-subunit had higher sensitivity to threonine, compared with the preparation without a detectable amount of the $\beta$-subunit. This suggests a possible role of the $\beta$-subunit in modulating the Thermus aspartokinase activity. From these observations, we assume that threonine may bind to the $\beta$ subunit (and also to the $\mathrm{COOH}$-terminal portion of the $\alpha$ subunit) for the modulation of the enzyme activity, and that the end-product inhibition by threonine is more effective when the enzyme is in the form of a heterooligomer (possibly an $\alpha_{2} \beta_{2}$ tetramer).

\section{ACKNOWLEDGEMENTS}

We are grateful to A. Iida (Tokyo Research Laboratories, Kyowa Hakko Kogyo Co.) for his advice on the measurement of the PRT activity.

\section{REFERENCES}

Bradford, M. M. (1976). A rapid and sensitive method for the quantitation of microgram quantities of protein utilizing the principle of protein-dye binding. Anal Biocbem 72, 248-254.

Buck, D., Spencer, M. E. \& Guest, J. R. (1985). Primary sequence of the succinyl-CoA synthetase from Escherichia coli. Biochemistry 24, 6245-6252.

Cassan, M., Parsot, C., Cohen, G. N. \& Patte, J.-C. (1986). Nucleotide sequence of lys $C$ gene encoding the lysine-sensitive aspartokinase III of Escherichia coli K12. J Biol Chem 261, 1053-1057.

Chen, N.-Y. \& Paulus, H. (1988). Mechanism of expression of the overlapping genes of Bacillus subtilis aspartokinase II. J Biol Chem 263, 9526-9532.

Chen, N.-Y., Hu, F.-M. \& Paulus, H. (1987). Nucleotide sequence of the overlapping genes for the subunits of Bacillus subtilis aspartokinase II and their control region. $J$ Biol Chem 262, 8787-8798.

Chen, N.-Y. Zhang, J.-J. \& Paulus, H. (1989). Chromosomal location of the Bacillus subtilis aspartokinase II gene and nucleotide sequence of the adjacent genes homologous to $w v r C$ and trx of Escherichia coli. $J$ Gen Microbiol 135, 2931-2940.

Cirillo, J. D., Weisbrod, T. R., Pascopella, L., Bloom, B. R. \& Jacobs, W. R., Jr (1994). Isolation and characterization of the aspartokinase and aspartate semialdehyde dehydrogenase operon from mycobacteria. Mol Microbiol 11, 629-639.

Cohen, G. N. (1985). Aspartate kinases I, II, and III from Escherichia coli. Methods Enzymol 113, 596-599.

Darlison, M. G. \& Guest, J. R. (1984). Nucleotide sequence of the iron-sulphur protein subunit of the succinate dehydrogenase of Escherichia coli. Biocbem J 223, 507-517. 
Darlison, M. G., Spencer, M. E. \& Guest, J. R. (1984). Nucleotide sequence of the $\operatorname{suc} A$ gene encoding the 2-oxoglutarate dehydrogenase of Eschericbia coli K12. Eur J Biochem 141, 351-359.

Duchange, N., Zakin, M. M., Ferrara, P., Saint Girons, I., Park, I., Tran, S. V., Py, M.-C. \& Cohen, G. N. (1983). Structure of the metJBLF cluster in Escherichia coli K12. $J$ Biol Chem 258, 14868-14871.

Grunstein, M. \& Hogness, D. S. (1975). Colony hybridization: a method for isolation of cloned DNAs that contain a specific gene. Proc Natl Acad Sci USA 72, 3961-3965.

Heard, J. T., Jr, Butler, M. A., Baptist, J. N. \& Matney, T. S. (1975). Chromosomal location of mutations affecting the electrophoretic mobility of malate dehydrogenase in Escherichia coli K-12. J Bacteriol 122, 329-331.

lijima, S., Uozumi, T. \& Beppu, T. (1986). Molecular cloning of Thermus flavus malate dehydrogenase gene. Agric Biol Chem 50, 589-592.

Jolly, D. J., Okayama, H., Berg, P., Esty, A. C., Filpula, D., Bohlen, P., Johnson, G. G., Shively, J. E., Hunkapillar, T. \& Friedmann, T. (1983). Isolation and characterization of a full-length expressible cDNA for human hypoxanthine phosphoribosyltransferase. Proc Natl Acad Sci US A 80, 477-481.

Kalinowski, J., Bachmann, B., Thierbach, G. \& Puhler, A. (1990). Aspartokinase genes $l y s C \alpha$ and $l y s C \beta$ overlap and are adjacent to the aspartate $\beta$-semialdehyde dehydrogenase gene asd in Corynebacterium glutamicum. Mol \& Gen Genet 224, 317-324.

Kalinowski, J., Cremer, J., Bachmann, B., Eggeling, L., Sahm, H. \& Puhler, A. (1991). Genetic and biochemical analysis of the aspartokinase from Corynebacterium glutamicum. Mol Microbiol 5, 1197-1204.

Katinka, M., Cossart, P., Sibilli, L., Saint Girons, I., Chalvignac, M. A., Le Bras, G., Cohen, G. N. \& Yaniv, M. (1980). Nucleotide sequence of the $\operatorname{tbr} A$ gene of Escherichia coli. Proc Natl Acad Sci US $A$ 77, 5730-5733.

Lu, Y., Shevtchenko, T. N. \& Paulus, H. (1992). Fine-structure mapping of cis-acting control sites in the lysC operon of Bacillus subtilis. FEMS Microbiol Lett 92, 23-28.

Messing, J. (1983). New M13 vectors for cloning. Methods Enzymol 101, 20-78.

Moir, D. \& Paulus, H. (1977). Properties and subunit structure of aspartokinase II from Bacillus subtilis VB217. J Biol Chem 252, 4648-4654.

Nishiyama, M., Matsubara, N., Yamamoto, K., lijima, S., Uozumi, T. \& Beppu, T. (1986). Nucleotide sequence of the malate dehydrogenase gene of Thermus flavus and its mutation directing an increase in enzyme activity. $J$ Biol Chem 261, 14178-14183.

Nishiyama, M., Horinouchi, S. \& Beppu, T. (1991). Characterization of an operon encoding succinyl-CoA synthetase and malate dehydrogenase from Thermus flavus AT-62 and its expression in Escherichia coli. Mol \& Gen Genet 226, 1-9.

Pratt, D. \& Subramani, S. (1983). Nucleotide sequence of the Escherichia coli xanthine-guanine phosphoribosyltransferase gene. Nucleic Acids Res 11, 8817-8823.

Saito, H. \& Miura, K. (1963). Preparation of transforming deoxyribonucleic acid by phenol treatment. Biochim Biophys Acta 72, 619-629.

Sanger, F., Nicklen, S. \& Coulson, A. R. (1977). DNA sequencing with chain-terminating inhibitors. Proc Natl Acad Sci USA 74, 5463-5467.

Southerland, P. \& McAlister-Henn, L. (1985). Isolation and expression of the Eschericbia coli gene encoding malate dehydrogenase. J Bacteriol 163, 1074-1079.

Southern, E. M. (1975). Detection of specific sequences among DNA fragments separated by agarose gel electrophoresis. $J \mathrm{Mol} \mathrm{Biol}$ 98, 503-517.

Spencer, M. E., Darlison, M. G., Stephens, P. E., Duckenfield, I. K. \& Guest, J.R. (1984). Nucleotide sequence of the $s u c B$ gene encoding the dihydrolipoamide succinyltransferase of Escherichia coli $\mathrm{K} 12$ and homology with the corresponding acetyltransferase. Eur J Biochem 141, 361-374.

Theze, J. \& Saint Girons, I. (1974). Threonine locus of Escherichia coli K-12: genetic structure and evidence for an operon. $J$ Bacteriol 118, 990-998.

Tosaka, O., Enei, H. \& Hirose, Y. (1983). The production of L-lysine by fermentation. Trends Biotechnol 1, 70-76.

Wood, D., Darlison, M. G., Wild, R. J. \& Guest, J. R. (1984). Nucleotide sequence of the flavoprotein and hydrophobic subunits of the succinate dehydrogenase of Escherichia coli. Biochem $J$ 222, 519-534.

Yanisch-Perron, C., Vieira, J. \& Messing, J. (1985). Improved M13 phage cloning vectors and host strains: nucleotide sequence of the M13mp18 and pUC19 vectors. Gene 33, 103-119.

Zakin, M. M., Duchange, N., Ferrara, P. \& Cohen, G. N. (1983). Nucleotide sequence of the met $L$ gene of Escherichia coli.J Biol Chem 258, 3028-3031.

Received 13 October 1994; revised 16 January 1995; accepted 31 January 1995. 